\title{
Formulation and Evaluation of Orally Disintegrating Films of Levocetirizine Dihydrochloride
}

H. KATHPALIA* AND A. PATIL

Department of Pharmaceutics, Vivekanand Education Society's College of Pharmacy, Chembur, Mumbai-400 074, India

Kathpalia and Patil: Formulation and Evaluation of Levocetirizine Dihydrochloride

\begin{abstract}
The present investigation was undertaken with the objective of formulating taste-masked orally-disintegrating films of the bitter levocetirizine dihydrochloride to enhance the convenience and compliance by the elderly or paediatric or bedridden and non-cooperative patients due to its ease of administration. Scope of this study was to explore the film forming properties of various film formers like modified starch, pullulan, hydroxypropyl methylcellulose and polyvinyl alcohol-polyethylene glycol based polymers. Plasticizers like glycerin, propylene glycol, sorbitol and polyethylene glycol 400 were evaluated by studying their effect on folding endurance, peelablity and in vitro disintegration time. Films were prepared by solvent casting method. Drug-loaded films, which composed of the selected polymers with the suitable plasticizer showed excellent film forming capacity along with good folding endurance, in vitro disintegration time within 22 $s$ and $>95 \%$ drug release in $10 \mathrm{~min}$ as compared to marketed immediate release tablets, which showed on 30.4\% at the end of $10 \mathrm{~min}$ The films prepared were 30-40 $\mathrm{mg}$ in weight with pleasant taste with bitter active being successfully taste masked by a mixture of sucralose and monoammonium glycerrhizinate producing an extended sweetness profile. Furthermore, the orally disintegrating films were stable for at least 3 mon when stored at $40^{\circ}$ and $75 \%$ relative humidity. The formulation developed is simple, easy to prepare and economical with great applicability during the emergency cases such as allergic reactions, whenever immediate onset of action is desired.
\end{abstract}

Key words: Orally disintegrating, solvent-casting method, folding endurance, peel ability, Lycoat RS 720 , pullulan, HPMC E5, kollicoat IR, monoammonium glycerrhizinate

For the past one decade, there has been an enhanced demand for more patient-friendly and compliant dosage forms. As a result, the demand for developing new technologies has been increasing annually. Orally disintegrating films (ODF) have carved a niche amongst the oral drug delivery systems due to their high patient compliance ${ }^{[1-3]}$. United States Food and Drug Administration (USFDA) defined the fast dissolving oral thin films as "a thin, flexible, non-friable polymeric film strip containing one or more dispersed/dissolved active pharmaceutical ingredients, which is intended to be placed on the tongue for rapid in vitro disintegration or dissolution in the saliva prior to swallowing for delivery into the gastrointestinal tract"[4].

Levocetirizine dihydrochloride, a third-generation non-sedative antihistamine developed as the active enantiomer of the second-generation antihistamine cetirizine. Levocetirizine is rapidly and extensively absorbed following oral administration with a plasma elimination half-life ranging from $6-10 \mathrm{~h}^{[5]}$. In allergic cold and cough due to sore throat conditions, especially the elderly and paediatric, bedridden and non-cooperative patients experience difficulty in swallowing a tablet type of dosage form ${ }^{[6]}$.

The objective of the present research work was to develop taste masked ODF of levocetirizine dihydrochloride disintegrating within $30 \mathrm{~s}$ to enhance the convenience of administration to the patients to improve compliance. Various polymers like modified starch (Lycoat RS 720) ${ }^{[7,8]}$, pullulan ${ }^{[9,10]}$, hydroxypropyl methylcellulose (HPMC E-5) ${ }^{[11]}$ and polyvinyl alcoholpolyethylene glycol (PEG) based polymer (Kollicoat

This is an open access article distributed under the terms of the Creative Commons Attribution-NonCommercial-ShareAlike 3.0 License, which allows others to remix, tweak, and build upon the work non-commercially, as long as the author is credited and the new creations are licensed under the identical terms

Accepted 27 February 2017

Revised 07 December 2016

Received 25 July 2015

*Address for correspondence

E-mail: hkathpalia2007@rediffmail.com

March-April 2017 
IR) $)^{[12]}$ were evaluated for film forming capacity. Plasticizers like glycerin, propylene glycol (PG), sorbitol and PEG $400^{[13]}$ were evaluated by studying their effect on folding endurance, peelablity and in vitro disintegration time of the polymer films. Pleasant tasting ODF of levocetirizine dihydrochloride were prepared in which bitter active was successfully taste masked by a mixture of sucralose and monoammonium glycerrhizinate producing an extended sweetness profile ${ }^{[7,14]}$. The formulation developed was simple, easy to prepare and economical with great applicability and also giving faster in vitro drug dissolution rate as compared to the commercially available immediate release tablets.

\section{MATERIALS AND METHODS}

Levocetirizine dihydrochloride was gifted by Cipla Ltd. and sucralose was obtained from Ipca Labs. Polymers like pullulan were obtained from Gangwal Chemicals, Lycoat RS 720 from Roquette Pharma, HPMC E-5 from Colorcon Ltd., Kollicoat IR from BASF. monoammonium glycerrhizinate (Magnasweet) was obtained from Unicorn Natural Products Pvt. Ltd. All other chemicals and reagents were of analytical grade and were purchased from Loba Chemie, Mumbai.

\section{Screening of polymers for ODF:}

Lycoat RS 720 (25\%), pullulan (2-5\%), HPMC E-5 (5$15 \%)$ and Kollicoat IR (2-15\%) were evaluated as film forming agents and glycerin, PG, sorbitol and PEG 400 as plasticizers for their suitability in ODFs. Plasticizer was dissolved in small quantity of purified water and then the polymer was dissolved in it followed by deaeration by sonication. Films were cast on plastic petri plate and completely dried in oven at $60^{\circ}$.

The films were evaluated for film forming ability, folding endurance ${ }^{[15]}$, ease of peel ability, tackiness, uniformity and in vitro disintegration. The concentration of polymer, which formed smooth, homogeneous, nontacky, flexible, fast disintegrating and easily peelable film was selected for formulation of drug-loaded film.

Determination of threshold value of bitterness of levocetirizine dihydrochloride:

A panel comprising of six healthy volunteers (age 22-
25 y) were selected for this study. Prior consent has been taken from the participants as the study involved only holding the drug solution in the mouth for $30 \mathrm{~s}$ but not to swallow it. Then the solution was spitted out followed by rinsing the mouth with water. A series of solutions of levocetirizine dihydrochloride of concentrations $10,20,30,40$ and $50 \mu \mathrm{g} / \mathrm{ml}$ was prepared in phosphate buffer of $\mathrm{pH}$ 6.8. The volunteers were asked to hold $10 \mathrm{ml}$ of each solution in oral cavity for $30 \mathrm{~s}$ and rate the taste on a scale from 0 to 4 (0: no bitterness, 1: threshold bitterness, 2: bitter, 3: moderate bitterness and 4 : strongly bitter). The mouth was rinsed with distilled water and a gap of 30 min was allowed between successive tests. Based on opinion of volunteers, threshold bitterness concentration of levocetirizine dihydrochloride was determined. Various trials were taken by physical mixture of the drug with sucralose, with and without peppermint powder, with and without Magnasweet to mask the bitter taste of the drug and the ratings obtained have been shown in Table 1.

\section{Preparation of drug-loaded films:}

Drug-loaded films were prepared by solvent casting method $^{[16]}$ for the optimized film compositions of each polymer. Levocetirizine dihydrochloride was incorporated at a concentration of $5 \mathrm{mg}$ per $4 \mathrm{~cm}^{2}$ film area. Amount of drug added into the film forming solution was calculated by considering total amount of solution to be poured in order to obtain films with desired thickness when casted on the calculated total surface area of the petri plate. Weighed quantities of the polymer and plasticizer were added to $3 / 4^{\text {th }}$ the quantity of water, stirred until the polymer was dissolved and kept aside to remove the entrapped air. Levocetirizine dihydrochloride along with water soluble sweetener sucralose and monoammonium glycerrhizinate was dissolved in the remaining quantity of water and peppermint powder was then added to it under stirring. Both solutions were then mixed till a homogenous solution was obtained and then deaerated by sonication. Film was casted on plastic petri plate and completely dried at $60^{\circ}$. Dried films were peeled off and then stored in airtight container under dehumidified conditions until taken up for further evaluation.

TABLE 1: TASTE ATTRIBUTES RATING SCALE

\begin{tabular}{lcccc}
\hline Attributes & \multicolumn{4}{c}{ Rating scale } \\
\hline After taste & 1-no & 2- slight & 3- extreme & - \\
Flavour intensity & 1-not strong & 2- moderate & 3- strong & 4- very strong \\
Bitterness & 1-no bitterness & 2- bitterness at the end & 3- bitter & 4- extremely bitter \\
\hline
\end{tabular}




\section{Evaluation of drug-loaded ODF:}

The drug-loaded films obtained were evaluated for organoleptic and palatability characteristics. The thickness of each film was measured at five different locations (centre and four corners) using a vernier calliper. Data were represented as a mean $\pm \mathrm{SD}$ of triplicate films. Films were cut into $2 \times 2 \mathrm{~cm}$ square strips. The moisture uptake by the films was determined by exposing them to $75 \%$ relative humidity $(\mathrm{RH})$ at room temperature $\left(25 \pm 2^{\circ}\right)$ for one week ${ }^{[17]}$. The uptake of moisture by the films was measured and calculated as percent increase in weight. Tack is the tenacity with which the film adheres to an accessory that has been pressed into contact with the film. Tackiness evaluation ${ }^{[18]}$ was carried out by gently pressing the film between fingertips and results were noted in qualitative terms as tacky or non-tacky. Film softening upon storage was checked by storing the films in desiccators at room temperature for $48 \mathrm{~h}$. Films were then evaluated for softening and integrity.

The folding endurance of the film was determined by repeatedly folding one film at the same place till it broke. The number of times that film could be folded at the same place without breaking was noted; which gave the value of the folding endurance. In vitro disintegration time was determined by placing $(2 \times 2$ $\mathrm{cm}^{2}$ ) film in a glass Petri dish containing $6 \mathrm{ml}$ of distilled water. The time required for the film to break was noted as in vitro disintegration time. Typical disintegration time for ODFs is $5-30 \mathrm{~s}^{[19]}$. Test was conducted in triplicates. Drug content determination was done by dissolving three samples of $1 \mathrm{~cm}^{2}$ surface area of film in $0.1 \mathrm{~N}$ hydrochloric and then analysing the amount of drug by UV spectrophotometer at $231 \mathrm{~nm}$. The in vitro dissolution test was performed for each type of film using the USP dissolution apparatus II at $37 \pm 0.5^{\circ}$ with stirring speed of $50 \mathrm{rpm}$ in $900 \mathrm{ml} 0.1 \mathrm{~N}$ hydrochloric acid and this was compared to the dissolution profile obtained with marketed immediate release tablets, Xyzal $5 \mathrm{mg}$ under similar dissolution conditions. Film size required for dose delivery $\left(2 \times 2 \mathrm{~cm}^{2}\right)$ was used. Five $\mathrm{ml}$ aliquot of dissolution medium was collected at time intervals of 1, 2, 5, 10, 15 and 30 min and replaced with equal volumes of $0.1 \mathrm{~N}$ hydrochloric acid. The collected samples were filtered and the concentration of the dissolved levocetirizine dihydrochloride was determined using UV spectrophotometer at $231 \mathrm{~nm}$. The results were presented as an average of three such concentrations.

\section{Stability studies:}

Stability studies of optimized batch of ODFs were performed under accelerated stability conditions $\left(40 \pm 2^{\circ} / 75 \pm 5 \% \mathrm{RH}\right) \mathrm{kept}$ in stability testing chamber for three months according to International Conference on Harmonisation (ICH) guidelines. The samples were evaluated for their physical characteristics, in vitro drug dissolution and assay initially and at the end of 1 and 3 mon of storage period.

\section{RESULTS AND DISCUSSION}

The present study was undertaken to investigate polymers like Lycoat RS 720, pullulan, HPMC E-5 and Kollicoat IR for their film forming capacity. Preliminary trials (plain films) were undertaken for designing the orodispersible films where the effect of various concentrations of the different film-forming agents and plasticizers on the characteristics of the films was assessed. Initially investigation was focused on development of polymer films with uniform appearance, good peelability from substrate, nontackiness, optimum flexibility, in vitro disintegration time of less than $30 \mathrm{~s}$. Although no requirements for in vitro disintegration time have been specified for ODFs, a limit of $30 \mathrm{~s}$ was decided as a selection criterion for screening studies.

As per results of evaluation tests given in Table 2 and 3, Lycoat RS 720 at concentration of $25 \% \mathrm{w} / \mathrm{w}$ formed films with good peelability, while at lower concentration of $10 \% \mathrm{w} / \mathrm{w}$, no film formation was observed. To impart flexibility and improve wetting property of Lycoat films, PG and polysorbate 80 were added. At $2 \% \mathrm{w} / \mathrm{w}$ concentration of $\mathrm{PG}$, film was found to be brittle with low folding endurance. Hence PG concentration was increased to $4 \% \mathrm{w} / \mathrm{w}$, which resulted in flexible film formation with good folding endurance. For both the trials, polysorbate 80 concentration was fixed i.e. $2 \%$ w/w. But Lycoat films were nondisintegrating at both the concentrations of PG; hence PG was replaced with sorbitol. Sorbitol was tried at $2 \%$ and $4 \% \mathrm{w} / \mathrm{w}$ concentration. It was observed that at $4 \% \mathrm{w} / \mathrm{w}$ concentration of sorbitol, film flexibility was maintained without affecting the stability. It was later found that in combination with soya lecithin, polysorbate was required in smaller concentration. $0.1 \% \mathrm{w} / \mathrm{w}$ polysorbate 80 and $0.8 \% \mathrm{w} / \mathrm{w}$ soya lecithin was incorporated in the films to aid in wetting and dissolution of film. No film softening upon storage was observed. Thus the polymer film of batch number 
TABLE 2: PHYSICO-MECHANICAL PROPERTIES OF LYCOAT RS 720 POLYMER FILMS

\begin{tabular}{lccccc}
\hline Formulation & LF01 & LF02 & LF03 & LF04 & LF05 \\
\hline Film forming capacity & Poor & Poor & Very good & Good & Good \\
Peelability & Non-peelable & Non-peelable & Peelable & $\begin{array}{c}\text { Brittle during } \\
\text { peeling }\end{array}$ & Non-peelable \\
& Transparent & Transparent & Transparent & Transparent & Transparent \\
Appearance & Non-tacky & Non-tacky & Non-tacky & Tacky & Non-tacky \\
Tackiness & - & 4 & 29 & 9 & 11 \\
$\begin{array}{l}\text { Folding endurance } \\
\text { In vitro disintegration } \\
\text { time (s) }\end{array}$ & Non-disintegrating & Non-disintegrating & Non-disintegrating & 38 & 31 \\
$\begin{array}{l}\text { Film softening at } \\
\text { 25 }, 60 \% \text { RH }\end{array}$ & Softening & Softening & Softening & No film softening & No film softening \\
Inference & No film formation & Brittle films Low & Non disintegrating & Brittle films & Non-peelable \\
Acceptability & folding endurance & film & No & No & No \\
\hline
\end{tabular}

TABLE 3: PHYSICO-MECHANICAL PROPERTIES OF LYCOAT RS 720 POLYMER FILMS (CONTINUED)

\begin{tabular}{|c|c|c|c|c|}
\hline Formulation & LF06 & LF07 & LF08 & LF09 \\
\hline Film forming capacity & Good & Good & Good & Very good \\
\hline Peelability & Peelable & Peelable & Peelable & Peelable \\
\hline Appearance & Transparent & Transparent & Transparent & Transparent \\
\hline Tackiness & Tacky & Non-tacky & Slight tacky & Non-tacky \\
\hline Folding endurance & 28 & 20 & 33 & 31 \\
\hline $\begin{array}{l}\text { In vitro disintegration time } \\
\text { (s) }\end{array}$ & 36 & 29 & 21 & 18 \\
\hline $\begin{array}{l}\text { Film softening at } 25^{\circ}, 60 \% \\
\text { RH }\end{array}$ & No film softening & No film softening & No film softening & No film softening \\
\hline Inference & Tacky & $\begin{array}{l}\text { Folding endurance } \\
\text { need to be improved }\end{array}$ & Slight tacky & Optimum \\
\hline Acceptability & No & No & No & Yes \\
\hline
\end{tabular}

LF09 had acceptable film properties and hence it was selected for drug loading.

As per the results of evaluation tests given in Table 4; pullulan formed good peelable film at $2 \% \mathrm{w} / \mathrm{w}$ and $5 \%$ $\mathrm{w} / \mathrm{w}$ concentration with in vitro disintegration time of less than $30 \mathrm{~s}$. Hence lower concentration of pullulan was selected for further trials. Effect of different plasticizers was studied. Sorbitol was selected, which showed good folding endurance and no film softening. Thus $5 \% \mathrm{w} / \mathrm{w}$ pullulan film of batch number PF05 containing $0.5 \%$ sorbitol had acceptable film properties hence was selected for drug loading.

As per results of evaluation tests given in Table 5, HPMC E-5 formed good peelable film at 5\% w/w. Effect of different plasticizers was studied at $0.7 \%$ concentration with $0.1 \%$ polysorbate. PG was selected as it gave the least D.T. Further trial was carried out with increasing concentration of HPMC from 5 to $7 \%$ to increase the thickness of the film along with $1 \%$ PG. In vitro disintegration time in $6 \mathrm{ml}$ water was 10 s; hence HF05 was the optimized batch, which was selected for drug loading.
The present study revealed that Kollicoat IR did not form a film at $2 \%$ concentration but formed good peelable film at 5 and $10 \% \mathrm{w} / \mathrm{w}$ concentrations. Film softening was seen with $5 \%$ concentration of Kollicoat IR; hence $10 \%$ concentration was finalized. Polysorbate $80(0.1 \%)$ was added as wetting agent. From the results as shown in Table 6, batch KF03 had acceptable film properties; hence it was selected for drug loading. Solvent casting being most preferred offered great uniformity and films had fine gloss and better physical properties. The films were easy to prepare without the use of organic solvents.

Most volunteers reported that $20 \mu \mathrm{g} / \mathrm{ml}$ as the threshold value of bitterness of levocetirizine dihydrochloride. This shows that the drug is extremely bitter and requires efficient taste masking method before formulating as orally disintegrating dosage forms. In order to ensure patient compliance and to allow the mouth disintegrating films to become a viable delivery system, bitterness masking becomes essential. Taste masking of levocetirizine dihydrochloride, which is extremely bitter was successfully achieved using a 
TABLE 4: PHYSICO-MECHANICAL PROPERTIES OF PULLULAN POLYMER FILMS

\begin{tabular}{|c|c|c|c|c|c|}
\hline Formulation & PF01 & PF02 & PF03 & PF04 & PF05 \\
\hline Film forming capacity & Good & Good & Good & Good & Very good \\
\hline Peelability & Non-peelable & Peelable & Peelable & $\begin{array}{l}\text { Brittle during } \\
\text { peeling }\end{array}$ & Easily peelable \\
\hline Appearance & Transparent & Transparent & Transparent & Opaque & Transparent \\
\hline Tackiness & Non-tacky & Non-tacky & Tacky & Non-tacky & Non-tacky \\
\hline Folding endurance & 20 & 35 & 29 & 30 & 40 \\
\hline $\begin{array}{l}\text { In vitro disintegration } \\
\text { time (s) }\end{array}$ & 28 & 16 & 20 & 18 & 15 \\
\hline $\begin{array}{l}\text { Film softening at } 25^{\circ} \text {, } \\
60 \% \mathrm{RH}\end{array}$ & Softening & No film softening & Softening & Softening & No film softening \\
\hline Inference & $\begin{array}{l}\text { Low folding } \\
\text { endurance }\end{array}$ & $\begin{array}{l}\text { Good folding } \\
\text { endurance }\end{array}$ & $\begin{array}{l}\text { Brittle and } \\
\text { tacky }\end{array}$ & Brittle films & Optimum \\
\hline Acceptability & No & No & No & No & Yes \\
\hline
\end{tabular}

TABLE 5: PHYSICO-MECHANICAL PROPERTIES OF HPMC E-5 POLYMER FILMS

\begin{tabular}{|c|c|c|c|c|c|c|}
\hline Formulation & HF01 & HF02 & HF03 & HF04 & HF05 & HFO6 \\
\hline $\begin{array}{l}\text { Film forming } \\
\text { capacity }\end{array}$ & Good & Good & Very good & Good & Very good & Poor \\
\hline Peelability & Peelable & Peelable & Easily peelable & Peelable & Easily peelable & Non-peelable \\
\hline Appearance & Transparent & Opaque & Transparent & Transparent & Transparent & Transparent \\
\hline Tackiness & Non-tacky & Non-tacky & Non-tacky & Non-tacky & Non-tacky & Tacky \\
\hline Folding endurance & 20 & 22 & 35 & 25 & 40 & - \\
\hline $\begin{array}{l}\text { In vitro } \\
\text { disintegration time } \\
\text { (s) }\end{array}$ & 20 & 16 & 10 & 15 & 10 & - \\
\hline $\begin{array}{l}\text { Film Softening at } \\
25^{\circ}, 60 \% \mathrm{RH}\end{array}$ & Softening & Softening & $\begin{array}{l}\text { No film } \\
\text { softening }\end{array}$ & Softening & $\begin{array}{l}\text { No film } \\
\text { softening }\end{array}$ & Softening \\
\hline Inference & $\begin{array}{l}\text { Low folding } \\
\text { endurance }\end{array}$ & $\begin{array}{l}\text { Film formed } \\
\text { was not } \\
\text { uniform }\end{array}$ & $\begin{array}{l}\text { Less D.T } \\
\text { compare to } \\
\text { others }\end{array}$ & Brittle films & Optimum & $\begin{array}{l}\text { Film was not } \\
\text { formed }\end{array}$ \\
\hline Acceptability & No & No & Yes & No & Yes & No \\
\hline
\end{tabular}

TABLE 6: PHYSICO-MECHANICAL PROPERTIES OF KOLLICOAT IR POLYMER FILMS

\begin{tabular}{|c|c|c|c|c|}
\hline Formulation & KF01 & KF02 & KF03 & KF04 \\
\hline Film forming capacity & Poor & Good & Very good & Poor \\
\hline Peelability & Non-peelable & Peelable & Easily peelable & Non-peelable \\
\hline Appearance & - & Transparent & Transparent & - \\
\hline Tackiness & - & Non-tacky & Slight tacky & - \\
\hline Folding endurance & - & 30 & 37 & - \\
\hline $\begin{array}{l}\text { In vitro disintegration time } \\
\text { (s) }\end{array}$ & - & 29 & 21 & - \\
\hline Film Softening at $25^{\circ}, 60 \% \mathrm{RH}$ & softening & softening & No film softening & softening \\
\hline Inference & $\begin{array}{l}\text { Film was not } \\
\text { formed }\end{array}$ & Non-uniform film & Optimum & $\begin{array}{l}\text { Film was not } \\
\text { formed }\end{array}$ \\
\hline Acceptability & No & No & Yes & No \\
\hline
\end{tabular}

combination of sucralose as the sweetener, peppermint as flavour and monoammonium glycerrhizinate as the flavour enhancer and bitter taste masking agent. Sucralose as a sweetener has an initial burst of sweetness, which dissipates rapidly but in combination with monoammonium glycerrhizinate, which is a flavour enhancer produced a sweetness profile that extended itself over the time of the product being experienced in the mouth. From the scores given by volunteers for the taste masking trials (Table 7); the batch F03 with sucralose $2 \mathrm{mg}$, peppermint powder 2 $\mathrm{mg}$ and monoammonium glycerrhizinate $0.2 \mathrm{mg}$ was selected as effectively taste masked batch.

Drug loading in the optimized formula for each polymer (Table 8) was successful without any change in film characteristics. Results of evaluation tests performed for 
the characterization of levocetirizine dihydrochloride ODFs are given in Table 9. Films of formula LODF01 were non-tacky, smooth and transparent with thickness of $0.2 \mathrm{~mm}$. Also in vitro dissolution time of this film was within $30 \mathrm{~s}$; hence it was observed that drug loading did not affect the properties of Lycoat polymer films. Drug-loaded pullulan film was non-tacky, transparent and disintegrated in $15 \mathrm{~s}$. HPMC E-5 film containing levocetirizine dihydrochloride disintegrated within $10 \mathrm{~s}$. Film obtained was non-tacky, transparent and folding endurance was 40. Drug-loaded Kollicoat IR film was non-tacky, flexible, and transparent and disintegrated within $21 \mathrm{~s}$. Kollicoat IR consists of $75 \%$ polyvinyl alcohol and $25 \%$ of PG hence there was no need for additional plasticizer.

In vitro dissolution study of all the batches showed $>95 \%$ drug dissolution in $10 \mathrm{~min}$, whereas the marketed immediate release tablets of levocetirizine dihydrochloride, Xyzal $5 \mathrm{mg}$ tablets shows only $30.4 \%$ dissolution in $10 \mathrm{~min}$ and $101.9 \%$ dissolution in $30 \mathrm{~min}$ (fig. 1). It was found that the optimized formulations were stable for at least three months at accelerated condition $\left(40 \pm 2^{\circ} / 75 \pm 5 \% \mathrm{RH}\right)$ as no significant change in appearance, thickness, folding endurance, in vitro disintegration time, drug content and in vitro dissolution time and extent was observed (Table 10 and 11).

Lycoat RS 720 (25\%), pullulan (5\%), HPMC E-5 (7\%) and Kollicoat IR (5\%) of levocetirizine formed flexible, peelable, transparent fast dissolving films weighing around $50 \mathrm{mg}$ and showing disintegration time within 30 s. The films showed faster drug release and dissolution as compared to commercial immediate release tablets and were attractive in appearance and produced sweet after taste, thus fulfilling the objectives of the present research work. These ODF can yield significantly better or at least comparable pharmacokinetic profile (AUC, $\mathrm{T}_{\max }, \mathrm{C}_{\max }$ ) as the conventional immediate release solid dosage forms ${ }^{[20]}$ and hence may prove to be more efficacious. The present research work demonstrated that the bitter taste of water soluble drug levocetrizine dihydrochloride can be completely eliminated by a combination of sucralose, peppermint powder and monoammonium glycerrhizinate, which

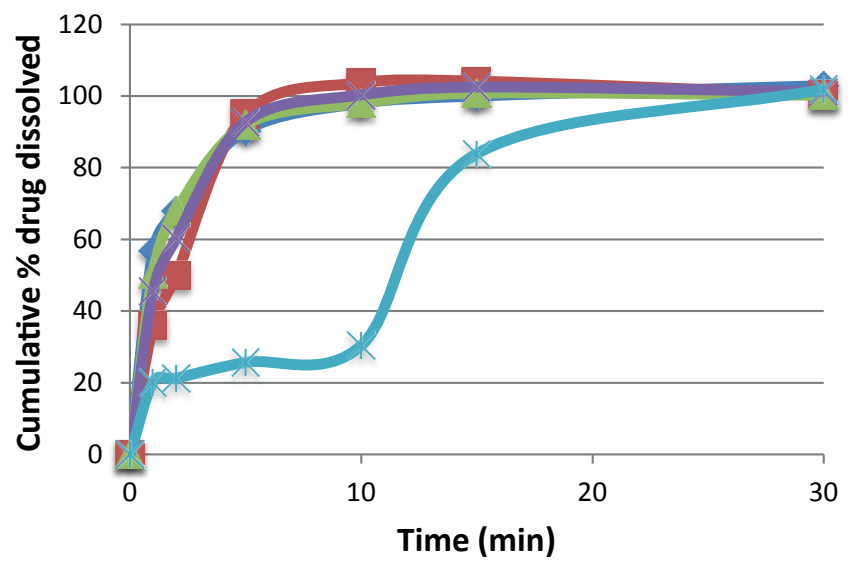

Fig. 1: In vitro drug dissolution profile of ODF vs. immediate release marketed tablet

- - LODF01; - - LODF02; - $\triangle-$ LODF03; - - LODF04; - *IR marketed tablets

TABLE 7: TASTE SCORING GIVEN BY VOLUNTEERS

\begin{tabular}{lccc}
\hline Batch No & After taste & Flavour intensity & Bitterness \\
\hline F01 & 3 & 1 & 3 \\
F02 & 2 & 1 & 3 \\
F03 & 1 & 2 & 1 \\
\hline
\end{tabular}

TABLE 8: OPTIMIZED COMPOSITION OF LEVOCETIRIZINE DIHYDROCHLORIDE ODF

\begin{tabular}{lcccc}
\hline Ingredients & \multicolumn{4}{c}{ Concentration (\%w/w) } \\
\cline { 2 - 5 } & LODF01 (Lycoat RS 720) & LODF02 (Pullulan) & LODF03 (HPMC E-5) & LODF04 (Kollicoat IR) \\
\hline Lycoat RS 720 & 25 & - & - & - \\
Pullulan & - & 5 & - & - \\
HPMC E-5 & - & - & 7 & - \\
Kollicoat IR & - & - & - & 10 \\
Polysorbate 80 & 0.1 & 0.1 & 0.1 & 0.1 \\
Soy lecithin & 0.8 & - & - & - \\
Sorbitol & 4 & 0.5 & - & - \\
Propylene glycol & - & - & 1 & - \\
Sucralose & 1 & 1 & 1 & 1 \\
Monoammonium & 0.1 & 0.1 & 0.1 & 0.1 \\
glycerrhizinate & & & & 0.8 \\
Peppermint powder & 0.8 & 0.8 & 0.8 & 0.8 \\
Purified water & q.s. & q.s. & q.s.
\end{tabular}


www.ijpsonline.com

TABLE 9: PHYSICO-CHEMICAL PROPERTIES OF LEVOCETIRIZINE DIHYDROCHLORIDE ODF

\begin{tabular}{lcccc}
\hline PARAMETERS & $\begin{array}{c}\text { LODF01 } \\
\text { LYCOAT }\end{array}$ & $\begin{array}{c}\text { LODF02 } \\
\text { PULLULAN }\end{array}$ & $\begin{array}{c}\text { LODF03 } \\
\text { HPMC E-5 }\end{array}$ & $\begin{array}{c}\text { LODF04 } \\
\text { KOLLICOAT IR }\end{array}$ \\
\hline Appearance & $\begin{array}{c}\text { Smooth surface and } \\
\text { transparent } \\
\text { Sweet and minty } \\
\text { Smooth taste }\end{array}$ & $\begin{array}{c}\text { Smooth surface and } \\
\text { transparent } \\
\text { Sweet and minty } \\
\text { Smooth taste }\end{array}$ & $\begin{array}{c}\text { Smooth surface and } \\
\text { transparent } \\
\text { Sweet and minty } \\
\text { smooth taste }\end{array}$ & $\begin{array}{c}\text { Smooth surface and } \\
\text { transparent } \\
\text { Sweet and minty } \\
\text { smooth taste }\end{array}$ \\
Tack test & Non-tacky & Non-tacky & Non-tacky & Non-tacky \\
\%Moisture uptake & 0.46 & 0.6 & 0.82 & 0.62 \\
Thickness (mm) & 0.2 & 0.2 & 0.2 & 0.2 \\
In vitro disintegration time (s) & 18 & 15 & 10 & 21 \\
Folding endurance & 31 & 40 & 40 & 37 \\
Film softening upon storage & No film softening & No film softening & No film softening & No film softening \\
\%Drug content & 98.29 & 101.36 & 99.2 & 102 \\
Inference & Acceptable & Acceptable & Acceptable & Acceptable \\
\hline
\end{tabular}

TABLE 10: STABILITY DATA OF LYCOAT AND PULLULAN ODF

\begin{tabular}{|c|c|c|c|c|c|c|c|}
\hline \multirow{3}{*}{$\begin{array}{l}\text { Physical } \\
\text { parameters }\end{array}$} & \multirow{3}{*}{$\frac{\text { Conditions }}{\left({ }^{\circ} / \% \mathrm{RH}\right)}$} & \multicolumn{3}{|c|}{ LODF01 (Lycoat RS 720) } & \multicolumn{3}{|c|}{ LODF02 (Pullulan) } \\
\hline & & \multirow[t]{2}{*}{ Initial } & $30^{\text {th }}$ & $90^{\text {th }}$ & \multirow[t]{2}{*}{ Initial } & $30^{\text {th }}$ & $90^{\text {th }}$ \\
\hline & & & day & day & & day & day \\
\hline \multirow[t]{2}{*}{ Appearance } & $40 / 75$ & Transparent & Transparent & Transparent & Transparent & Transparent & Transparent \\
\hline & $25 / 60$ & Transparent & Transparent & Transparent & Transparent & Transparent & Transparent \\
\hline \multirow[t]{2}{*}{ Thickness (mm) } & $40 / 75$ & $0.2 \mathrm{~mm}$ & $0.2 \mathrm{~mm}$ & $0.2 \mathrm{~mm}$ & $0.2 \mathrm{~mm}$ & $0.2 \mathrm{~mm}$ & $0.2 \mathrm{~mm}$ \\
\hline & $25 / 60$ & $0.2 \mathrm{~mm}$ & $0.2 \mathrm{~mm}$ & $0.2 \mathrm{~mm}$ & $0.2 \mathrm{~mm}$ & $0.2 \mathrm{~mm}$ & $0.2 \mathrm{~mm}$ \\
\hline \multirow{2}{*}{$\begin{array}{l}\text { Folding } \\
\text { endurance }\end{array}$} & $40 / 75$ & 31 & 30 & 32 & 40 & 38 & 36 \\
\hline & $25 / 60$ & 32 & 29 & 30 & 35 & 33 & 30 \\
\hline \multirow{2}{*}{$\begin{array}{l}\% \text { Moisture } \\
\text { uptake }\end{array}$} & $40 / 75$ & 0.45 & 0.4 & 0.42 & 0.6 & 0.55 & 0.58 \\
\hline & $25 / 60$ & 0.52 & 0.42 & 0.48 & 0.55 & 0.5 & 0.48 \\
\hline In vitro & $40 / 75$ & 18 & 20 & 18 & 20 & 18 & 20 \\
\hline $\begin{array}{l}\text { disintegration } \\
\text { time }(\mathrm{s})\end{array}$ & $25 / 60$ & 20 & 22 & 20 & 20 & 22 & 20 \\
\hline \multirow[t]{2}{*}{ Assay \% } & $40 / 75$ & 98 & 98.5 & 101.5 & 101 & 102.2 & 102 \\
\hline & $25 / 60$ & 99 & 101 & 100.2 & 102 & 101.5 & 100.5 \\
\hline
\end{tabular}

TABLE 11: STABILITY DATA OF HPMC AND KOLLICOAT ODF

\begin{tabular}{|c|c|c|c|c|c|c|c|}
\hline \multirow{3}{*}{$\begin{array}{l}\text { Physical } \\
\text { parameters }\end{array}$} & \multirow{3}{*}{$\begin{array}{c}\text { Conditions } \\
\left({ }^{\circ} / \% \mathrm{RH}\right)\end{array}$} & \multicolumn{3}{|c|}{ LODF03 (HPMC) } & \multicolumn{3}{|c|}{ LODF04 (Kollicoat) } \\
\hline & & Initial & $30^{\text {th }}$ & $90^{\text {th }}$ & Initial & $30^{\text {th }}$ & $90^{\text {th }}$ \\
\hline & & & day & day & & day & day \\
\hline \multirow[t]{2}{*}{ Appearance } & $40 / 75$ & Transparent & Transparent & Transparent & Transparent & Transparent & Transparent \\
\hline & $25 / 60$ & Transparent & Transparent & Transparent & Transparent & Transparent & Transparent \\
\hline \multirow[t]{2}{*}{ Thickness (mm) } & $40 / 75$ & $0.2 \mathrm{~mm}$ & $0.2 \mathrm{~mm}$ & $0.2 \mathrm{~mm}$ & $0.2 \mathrm{~mm}$ & $0.2 \mathrm{~mm}$ & $0.2 \mathrm{~mm}$ \\
\hline & $25 / 60$ & $0.2 \mathrm{~mm}$ & $0.2 \mathrm{~mm}$ & $0.2 \mathrm{~mm}$ & $0.2 \mathrm{~mm}$ & $0.2 \mathrm{~mm}$ & $0.2 \mathrm{~mm}$ \\
\hline \multirow{2}{*}{$\begin{array}{l}\text { Folding } \\
\text { endurance }\end{array}$} & $40 / 75$ & 40 & 38 & 36 & 37 & 38 & 36 \\
\hline & $25 / 60$ & 35 & 36 & 30 & 32 & 30 & 35 \\
\hline \multirow{2}{*}{$\begin{array}{l}\text { \%Moisture } \\
\text { uptake }\end{array}$} & $40 / 75$ & 0.8 & 0.78 & 0.8 & 0.6 & 0.62 & 0.6 \\
\hline & $25 / 60$ & 0.58 & 0.6 & 0.65 & 0.58 & 0.58 & 0.65 \\
\hline \multirow{2}{*}{$\begin{array}{l}\text { In vitro } \\
\text { disintegration } \\
\text { time (s) }\end{array}$} & $40 / 75$ & 20 & 22 & 20 & 20 & 25 & 22 \\
\hline & $25 / 60$ & 25 & 22 & 24 & 22 & 23 & 21 \\
\hline \multirow[t]{2}{*}{ Assay \% } & $40 / 75$ & 99 & 100 & 101.5 & 101 & 102.2 & 102 \\
\hline & $25 / 60$ & 98 & 101.5 & 100.2 & 99.5 & 101.2 & 100.8 \\
\hline
\end{tabular}

can also give extended sweetness profile. Thus the development of paper thin ODF providing all the homogeneity advantages of a liquid formulation with convenience and stability of a solid dosage form can be a viable option when rapid action is required especially in case of non-cooperative patients.

\section{Acknowledgements:}

The authors thank Cipla Ltd. Mumbai, for providing 
levocetirizine dihydrochloride as gift sample for this work. They also thank Dr. (Mrs.) Supriya Shidhaye, Principal, VES College of Pharmacy, Mumbai for providing the required facilities to carry out this research work.

\section{Conflict of interest:}

There are no conflicts of interest.

\section{Financial support and sponsorship:}

Nil.

\section{REFERENCES}

1. Aurora J, Pathak V. Oral disintegrating dosage forms, an overview. Drug Del Tech 2005;5:50-54.

2. Bala R, Pawar P, Khanna S, Arora S. Orally dissolving strips: a new approach to oral drug delivery system. Int J Pharm Investig 2013;3:67-76.

3. Kathpalia $\mathrm{H}$, Gupte A. An introduction to fast dissolving oral thin film drug delivery system: a review. Curr Drug Deliv 2013;10:667-84.

4. http://www.accessdata.fda.gov/drugsatfda_docs/ nda/2015/022524orig1s000chemr.pdf.

5. https://www.drugbank.ca/drugs/DB06282.

6. Hirani J, Rathod D, Vadalia K. Orally Disintegrating Tablets: A Review. Trop J of Pharm Res 2009;8:161-72.

7. Kathpalia H, Sule B, Gupte A. Development and evaluation of orally disintegrating film of tramadol hydrochloride. Asian J Biomed Pharm Sci 2013;3:27-32.

8. Preis M, Pein M, Breitkreutz J. Development of a taste-masked orodispersible film containing dimenhydrinate. Pharmaceutics 2012;4:551-62.

9. Foss D, Hoffman A, Shen S, Stucky AM, Turner JL. Edible pullulan films containing flavouring. US Patent NumberUS20090011115A1;2009.
10. Renuka M, Avani A. Formulation and characterization of rapidly dissolving films of cetirizine hydrochloride using pullulan as a film forming agent. Indian J Pharm Educ Res 2011;45:72-7.

11. Daud A, Bonde M, Sapkal N, Gaikwad N. To study the effect of solvent, viscosity and temperature on mouth dissolving film of Withania somnifera linn. Asian J Pharm 2012;6:212-7.

12. Mahesh A, Shastri N, Sadanandam M. Development of taste masked fast disintegrating films of Levocetrizine Dihydrchloride for oral use. Curr Drug Deliv 2010;7:21-7.

13. Mishra R, Amin A. Formulation development of taste masked rapidly dissolving films of cetirizine hydrochloride. Pharm Tech 2009;33:48-56.

14. Myers GL, Hariharan MS, Davidson K, Sanghvi P. Stabilized amine-containing actives in oral film composition. US Patent Number-US9095577 2015;2015.

15. Panda BP, Dev NS, Rao MEB. Development of innovative orally fast disintegrating dosage forms: a review. Int J Pharm Sci Nanotech 2012;5:1666-74.

16. Hoffmann EM, Breitenbach A, Breitkreutz J. Advances in orodispersible films for drug delivery. Expert Opin Drug Deliv 2011;8:299-316.

17. Radhakishan UR, Chavan V, Tribhuvan N. Mouth dissolving films and their patents: An overview. Int Res J Pharm 2012;3:39-42.

18. Bhupinder B, Sarita J, Mandeep K, Harmanpreet S. Orally fast dissolving films: innovations in formulation and technology. Int J Pharm Sci Rev Res 2011;9:50-4.

19. Barnhart S. Thin film oral dosage forms. In: Rathborne MJ, Hadgraft J, Roberts MS, Lane ME, editors. Modified release drug delivery technology: Drugs and the pharmaceutical sciences. 2nd ed. New York: Marcel Dekker; 2008. p. 209-16.

20. Zhang H, Chen H, Li XJ, Zhang Q, Sun YF, Liu CJ, et al. Pharmacokinetics and safety profiles of novel diethylstilbestrol orally dissolving film in comparison with diethylstilbestrol capsules in healthy Chinese male subjects. Int J Clin Pharmacol Ther 2014;52:407-15. 